УДК 141

DOI 10.35423/2078-8142.2021.2.1.8

В. П. Волковський, кандидат філософських наук, науковий співробітник відділу історії філософії Украӥни, Інститут філософії імені Г. С. Сковороди НАН України, м. Київ, Украӥна e-mail:dinginnalu@gmail.com ORCID: https://orcid.org/0000-0002-4674-3956

\title{
СВІТОГЛЯДНО-ЦІННІСНІ ВИМІРИ ЛОКАЛЬНОЇ ПОЛТТИЧНОЇ СВІДОМОСТІ УКРАЇНИ: ДО АНАЛІЗУ СТРАТЕГІЙ ПОШИРЕННЯ І ЗБЕРЕЖЕННЯ ДОКТРИНИ «РУССКОГО МИРА»
}

Стаття аналізує стратегії поширення $i$ збереження доктрини «Русского мира», зосереджуючись на осмисленні патернів локальної політичної свідомості українського суспільства, базових циінностей і світоглядних орієнтацій, щุо впливають на політичнозначущу поведінку індивідів та спільнот в Україні. Автор спирається на філософську методологію, поєднуючи методи аналітичної філософії, феноменологї та герменевтики, а також напраџювання досліджень начієтворення $і$ постколоніальних суспільств. Це дає можсливість виокремити деякі базові патерни, не претендуючи на виключність чи остаточність висновку. До цих патернів автор зараховуе атомістичний індивідуалістичний патерналізм, який він ще називає оберненим патерналізмом, пануючі иінності безпеки, виживання, матеріалістично-гедоністичні орієнтації. Це накладається на публічне протистояння двох сакральних космосів або громадянських релігій, проте крім изих двох сторін протистояння ще виокремлюється третя найбільш масова иіннісна група. Автор пропонує практичні рекомендації для органів влади та публічного дискурсу.

Ключові слова: «русский мир», гібридна війна, суспільні иџінності, атомістичний індивідуалістичний патерналізм, обернений 
патерналізм, спіральна динаміка, колоніалізм, Nationalism Studies, Postcolonial Studies.

Публічні дискусії про політику України стосовно окупованих Криму та окремих районів Донецької і Луганської областей, ставлення тамтешнього населення до України і ставлення українського суспільства до тамтешнього населення, заторкує властиво філософський предмет: індивідуальний та колективний світогляд, цінності та ідеї, що мотивують людей до вибору, дій, вчинків. Ця болюча тема постійно поновлюється у ширшому контексті - теми «Південного Сходу», відносин «України» та «Південного Сходу». Загострення на фронті бойових дій, нові виборчі перегони, черговий скандал на грунті мови, партійних преференцій чи ставлення до Росії і російсько-української війни збурюють у суспільстві хвилі дегуманізації і ненависті, що часто-густо супроводжується іншуванням та тавруванням «півдня-сходу» як чогось ворожого, або, в ширшому значенні, взагалі цілого українського народу, як «неправильного». Це також породжує часті ситуації розчарування і знецінення, особливо серед активістів громадянського суспільства, що супроводжується висловлюваннями в дусі «розчарування у народі», «тут нічого зробити не можна», «як за таке можна голосувати». Захоплення «волелюбним, незламним, героїчним» українським народом доби Майдану часто змінюється розчаруванням у «патерналістському, совковому, відсталому народі».

Ці проблеми, як політичні, так і соціально-психологічні [8], вимагають глибокого осмислення стану речей, ставлення до ситуації та вироблення відповідної політики. Це завдання не є тривіальним, оскільки у вирішенні його ми стикаємось 3 багатьма перешкодами, зокрема й особливо, вадами дискурсу, ідеологемами і патернами пропаганди, що деформують наші моделі сприйняття і розуміння дійсності. Гібридні способи ведення війни містять кілька вагомих компонентів [11], з яких ми виокремимо два: маніпуляції 3 публічним дискурсом та інформаційна мобілізація населення на території умовного ворога.

Інформаційна війна передбачає роботу з населенням, перетворення його на свого союзника і на зброю проти ворога, і ця робота насамперед відбувається на ниві світоглядно-ціннісних пере- 
конань, ідей, що мотивують людей робити певні вчинки. Ефективність такої політики і протидії їй залежить, зокрема, від якості аналізу соціальної психології населення, яке є цільовою аудиторією, наскільки нам вдалося чітко з'ясувати фундаментальні ідеї, якими живуть і керуються ці люди, ці системи ідей та мотивацій, які впливають на процеси прийняття рішень. Ми повинні чітко уявляти світоглядно-ціннісний профіль населення цих територій, щоб виробити ефективну політику щодо них.

Натомість, поки що не спостерігається такого розуміння ні у представників державної влади, ні в академічній спільноті, ні у ширшому громадянському суспільстві. Хоча певні дослідження вже $\epsilon$, але основні висловлювання в публічному дискурсі були б неможливі, якби вони враховували елементарний моніторинг і розуміння ментальних процесів. Упродовж багатьох років так чи інакше ми займалися таким моніторингом, зокрема досліджуючи доктрину «русского мира» 3 філософської точки зору. 3 точки зору соціологічної методології це можна було б назвати якісним нерепрезентативним дослідженням на основі контент-аналізу.

Обраний підхід перебуває насамперед у філософській царині, що зумовлює певну методологічну особливість. Філософське дослідження, зважаючи на соціологічні, історичні, психологічні дані, абстрагує їх та намагається через герменевтичне розуміння вхопити певні ідеї, цінності, патерни, які визначають, формують і структурують людський світогляд. Нас цікавлять насамперед ідеї, що мотивують людей, а не їхня кількісна динаміка. «Завдання філософії - побудова та оцінення світоглядів» [1, с. 3], філософія взагалі $\epsilon$ справою «побудови та оцінення категоріальних систем» [1, с. 13]. Цей підхід у межах аналітичної філософії дає можливість зосередитись на спробі зрозуміти та реконструювати логіку світоглядів.

Саме і тільки філософський підхід може вхопити світогляд як цілісність, що формує екзистенційну основу особистості, індивіда, а відтак зрозуміти його і водночас, не вимагаючи згоди 3 ним, виробити стратегію комунікації. Це - баланс між емпатичним прийняттям Іншого з відмовою від (за)судження, з одного боку, логічною критикою в межах оперування поняттями істини і хиби - 3 другого боку, і самокритичною рефлексією над власною ж відмін- 
ністю між об'єктивними логіко-фактичними основами та суб' єктивними цінностями і відданостями (commitments).

У цьому аналізі ми не претендуємо ні на повноту охоплення, ні на вичерпність і остаточність висновків. Це радше поточне осмислення, що відкрите до наукових процедур фальсифікації.

Це аж ніяк не стаття про «ментальність якихось регіонів». Саме поняття «ментальності» цілого регіону віддає «метафізичним» (у поганому значенні цього слова) упередженням, яке конституює міфічну (у значенні міфу як наративу, згідно 3 О. Ф. Лосєвим) ідентичність «регіону Х» 3 його «народом X». Вочевидь, що там живуть різні люди з різними світоглядними орієнтаціями, щодо яких виклад даної статті буде цілком незастосовним. Йдеться радше про «ідеальний тип» (поняття М. Вебера) як певне операційне поняття, що дає можливість описати певну сукупність індивідів, їхні спільні світоглядно-ціннісні і соціальнопсихологічні характеристики, виокремити специфічну одиницю колективного імажинаріуму, тобто однієї із систем ідей, що циркулюють у суспільстві та структурують його світоглядний, власне імажинаторний рівень. Понад те, цей ідеальний тип виявляється притаманним далеко не лише «мешканцям регіону X», а й цілому українському суспільству.

Варто відзначити важливі для дослідження джерела: це, насамперед, соціологічні опитування, що проводились провідними соціологічними центрами (КМІС, група «Рейтинг», центр Разумкова та ін.), теоретичні напрацювання у сучасних Nationalism та Postcolonial Studies, розробку поняття «громадянської релігії» Роберта Белли (Bellah), концепції секуляризації П. Бергера, праці із соціальної психології Валерія Пекаря, що спираються на методологію спіральної динаміки Кена Вілбера (не єдину, але вельми застосовну модель опису соціальної динаміки), статті Свгена Глібовицького, Оксани Забужко, Ольги Ісаюк, Віктора Козловського, Сергія Квіта, Миколи Рябчука, Ольги Гнатюк та багатьох інших, кого не процитовано в даній статті, але чиї напрацювання були важливими для наших філософських узагальнень. 


\section{До ідей:}

матеріалізм, гедонізм, односторонній егоїстичний патерналізм

Перший погляд на військове протистояння справляє враження, що триває боротьба двох великих метанаративів, великих ідеологій (умовно кажучи, української та російсько-радянської). Проте трохи глибший моніторинг засвідчує, що в ієрархії потреб населення України, особливо на умовних півдні і сході, панують нижчі рівні піраміди Маслоу [2]. Виживання, безпека, харчування, елементарна забезпеченість безумовно панують над будь-якими «високими матеріями».

Окремі соціологічні дослідження засвідчують, що безпекова та гедоністична цінності разом домінують в українському суспільстві [14]. Водночас, будь-які такі дослідження повинні враховувати відмінності публічної декларації власних цінностей (яку фіксують такі дослідження) і повсякденної практики оцінювання власних і чужих дій, слів, намірів, що не вхоплюється жодними такими опитуваннями.

Це дуже помітно в оцінці подій - розмови про те, «де більше платять», «що вам дала», «дешеву ковбасу і великі зарплати в СРСР» добре свідчать, що людьми рухає насамперед матеріальна, економічна складова [5].

Цим визначаються майже всі царини світоставлення - політичні, гендерні, сімейні, економічні, побутові. Головний критерій успіх, що вимірюється у грошах та впливі. «Шановані люди»- це ті, хто можуть собі все дозволити, маючи гроші, вплив, владу. Діяльність, що не приносить зиску, часто-густо зневажається: «що тобі дасть та філософія?». Політичне оцінюється так само: «що тобі дала ця Україна? он у Росії зарплати більше» тощо.

Відзначимо, що це не означає, що масово люди $є$ цинічні прагматики-гедоністи-споживачі. Цінності доброти чи універсалізму не менш значущі - бути альтруїстами і вболівати за інших (старих, бідних тощо), говорити не про свій зиск, навіть будучи бідним, але про благо іншого, навіть шанувати неутилітарні професії і мистецтва. Проте турбота і переживання виражається саме у матеріальному, у нижчих рівнях, за А. Маслоу, - вони оцінюють благо і зло для інших передусім у матеріальному еквівалентні (напри- 
клад, люди цінують високу зарплату в СРСР, а відсутність свободи чи гідності - не розуміють, що це є щось суттєве) [10].

Існує усталена думка, що проросійське населення характеризується патерналізмом. Проте це доволі специфічний патерналізм. Люди вважають, що держава повинна ними опікуватися і забезпечувати певний рівень життя, стандарт культури, правосуддя і безпеку, обов'язково - саме держава повинна дати гідні зарплати і пенсіі, тобто забезпечити матеріальний рівень існування. Але бракує важливої для типового патерналізму риси - хліб в обмін на свободу. Пострадянська людина, навіть на Сході чи Півдні України, не дуже сприймає контроль будь-кого над собою. Вона «косить» від армії, не зважає на загальні гасла та державницькі ідеї. «Я сам по coбi» - це радикальний індивідуалізм, аж до соліптичного атомізму. Максимальна спільність, яка визнається, - це хіба що родинна спільність. Усе, що більше, мало сприймається. При цьому людина відмовляється від активної політичної дії, яка потребує співпраці 3 іншими, вона не довіряє такій співпраці, як «проплаченій» [5]. Такий атомістичний індивідуалістичний патерналізм можна назвати оберненим патерналізмом і описати таким афоризмом: «Мені всі (насамперед, держава) винні, я нікому нічого не винен». Це зовсім не типовий патерналізм - суспільство водночас екстремальноатомізоване з повною атрофією будь-якої суспільності, крім максимально інтимної (родина) і максимально абстрактної (держава).

«Влада» сприймається, з одного боку, абстрактно, а з іншого - дуже персоналізовано. Якщо виокремити чотири рівні політики [15] (політика облич, політика партій, політика інституцій і правил, політика ідей і цінностей), або інакше: конкретні особи можновладців, різні органи влади, держава як інституція, країна як Вітчизна і морально-політична цінність - то наше суспільство зупинилося на першому рівні. Говорячи про політику, владу і державу, люди максимально персоніфікують їх - у нас не лише «президент» дорівнює «конкретній Z», але вся держава, і Україна взагалі - це «Z». Як наслідок, коли мені не подобається «Z», я знецінюю всю Україну. Коли мені Кабмін підвищив пенсію, я кажу «Z мені 100 гривень додав». Що говорити про громадянську свідомість і політичну активність, коли образ влади - персоніфікований на рівні архаїчного суспільства навіть до часів фараонів? [16] I це на фоні комплексу 
«вивченої безпомічності»: «ти нічого не зможеш змінити, там все схоплено».

Таке світосприйняття зустрічається в усіх регіонах України ні мова, ні віра, ні уявлена (за Б. Андерсоном) політична ідентичність не скасовує такого базового ставлення до влади і держави. Це зумовлює панування, використовуючи класифікацію В. Пекаря за К. Вілбером [9], синього і червоного типу суспільства, основними цінностями якого є сила і влада (червоний тип), що поєднується 3 цінністю порядку і стабільності (синій тип).

\section{Сакральний час і простір: інериія, не традиція}

Перш ніж говорити про неутилітарні цінності, про уявлену ідентичність, яку поділяють люди, зауважимо, що така ідентичність спирається на певний сакральний космос (у термінах П. Бергера), який має свій сакральний час, який визначає наратив історичної «пам'яті», ï канон, уявленого «суб'єкта», шерег сакральних подій і постатей, і сакральний простір, який охоплює, позначає і структурує профанний простір. Міста, вулиці, календар пройняті певними точками, які позначають сакральних постатей, дати тощо. Цей сакральний простір може визначатись релігією, державою, різними спільнотами. Сакральний космос, відповідно, містить свою систему сакральних авторитетів - ідей, цінностей, постатей, яким приписується визначальна роль у позначенні, що $є$ (не)правильним (what's right, what's wrong), як в історії, так і в політиці.

В Україні розрізнення між регіонами починається саме тут: в одному регіоні в центрі міста стоїть пам'ятник Леніну чи Артему, центральна вулиця Леніна, парад на День Перемоги тощо. В іншому - пам'ятник Бандері, вулиця Шухевича, марш УПА.

Індивід, що виростає в певному регіоні, сприймає наявний сакральний часопростір некритично, як певну даність, яку всі вважають сакральною. Проте це не є «традицією». Українське суспільство в будь-якому регіоні важко назвати «традиційним» після XX ст., хоча на Заході більш вижили типові традиційні інститути [6]. Насамперед тому, що радянське суспільство, хоч би яким воно було, зазнало глибоких трансформаційних, певною мірою модерні- 
заційних процесів. Образом традиційності можна назвати сволок хати, де було вирізьблено імена предків до десятого коліна, або аристократичний палац 3 портретами великих предків від часів Карла Великого. На практиці, у нас «традиція» сакрального часопростору не сягає більше життя двох-трьох поколінь [17].

\section{Уявлена спільність: три партії-ковбаси, Леніна і тризуба}

Саме тут починається неутилітарна складова світогляду населення. Ця спільність, насамперед, imagined - вона об'єднує людей в imagined community, яка далеко не завжди є нацією. У нашому контексті така уявлена ідентичність нагадує середньовічний феодальний вінегрет- багаторівнева ідентичність (конфесійна, політично-легітимістична (патерналістична), регіональна, етнічна, професійно-цехова тощо), рівні якої часто-густо існують незалежно одна від одної і перекривають, заважають. Проте від класичного феодалізму відрізняє риса оберненого патерналізму: є обов'язки сеньйора перед васалом, але васал не має обов'язків перед сеньйором. 3 одного боку, типово для феодалізму, влада гранично персоніфікована: це умовний «Пєтя» або «Ренат», якого шанують як «хозяїна», який має цей регіон як свою вотчину. Формальні інституції мало важливі - важлива воля «Хозяїна». Проте «Ренат» має забезпечувати порядок і стабільність у регіоні (типовий «синій» тип цінностей, за К. Вілбером) [9], але самі мешканці не повинні йому нічого давати, крім голосів на виборах (яких і так не жаль). Із «Ренатом» об'єднує насамперед символічна, уявлена спільність «наш господар і добродійник».

Уявлені спільноти є регіональні, конфесійні, професійні, проте нас цікавлять основні дві національно-державні. Одна украӥноцентричний сакральний космос, структурований довкола Києва та України. Друга - радянсько-російський сакральний космос, концентрований довкола радянського ідеологічного імажинаріуму, спадкоємцем якого проголосила себе РФ. Протистояння цих сакральних космосів активується під час будь-яких маніфестацій сакрального (тобто свят): будь-то день перемоги (центральний для міфології російсько-радянської свідомості), чи день народження Бандери, день Покрови, день Незалежності, спомин Голодомору і 
довкола будь-яких осердь сакрального (пам'ятники чи місця трагедій). Ми наочно бачимо протистояння взаємовиключних сакральних всесвітів [3].

Ця спільність формується насамперед ЗМІ, суспільним вихованням, роль медіа тут вирішальна - саме через них людина отримує трактування сакрального космосу. Саме успіх медіапропаганди став причиною суспільного протистояння, що вилилось, зрештою, у війну. Цьому сприяло, зокрема, новий рівень якості медіатехнологій, висока атомізація суспільства (в якому індивід радше довіряв «дяді з екрану», ніж реальним родичам і друзям), і вдала апеляція до «традиційного» (точніше, інерційного) сакрального космосу.

Російські 3МI реактивували дрімавший сакральний часопростір радянської доби з його системою сакральних авторитетів, сакралізованих друзів і ворогів. Ця активація зазнала поразки там, де панував інший сакральний космос [4], і де відбулась зустріч 3 реальністю. Насамперед, це Галичина з україноцентричним сакральним космосом, але і Центр України. Коли ти щодня спілкуєшся 3 живими україномовними людьми і тут тобі починають розказувати, що українська мова видумана - це миттєво призводить до провалу пропаганди, і навіть тотальна гегемонія парафій УПЦ МП і проросійських 3МІ не поможе. Цим пояснюється поступовий рух на схід україноцентричного сакрального космосу впродовж 19902000-х. Падіння СРСР позбавило радянський сакральний космос опертя на репресивну силу, і після нетривалого часу інерції та кволих спроб конструювання українського космосу радянський наратив став стрімко втрачати силу і вплив. Проте на Донбасі і в Криму ЗМІ і політикам вдалось поєднати регіональну уявлену ідентичність 3 радянсько-російською новою уявленою ідентичністю, активувавши старі сплячі патерни сакрального часопростору [12].

Отже, відбувається протистояння двох умовних «партій» (уявлених спільностей), на фоні яких панує третя «партія». Образно їх можна назвати «партія Леніна» або Москви, «партія тризуба» і «партія ковбаси». Йдеться про базові символи сакрального космосу: пам'ятники Леніну, українські державні символи, чи вже названий раніше егоїстичний обернений патерналізм 3 цінністю доб- 
робуту i анекдотичним образом «ковбаси по 2.20» (різновидом «ковбаси» $є$ «мир», «зарплата» чи «успіх»).

Ці «партії» далеко не монолітні. Наприклад, віряни УПЦ МП мають різні сакральні космоси, які можна назвати як «святоруський» (образ Триєдиної Русі, з основою в Росії), «києворуський» (образ Русі, але намагаючись підкреслити роль Києва), «православно-космополітичний» (байдуже на руськість, але головне - канонічність і православність) [18]. «Партія ковбаси» також не тотожна образу бабусь на лавці, що мріють про дешеву ковбасу і чекають роздачі гречки. Вона має свої різновиди, включаючи молоде покоління і людей середнього віку, які не так покладаються на державу, як вимагають, щоб вона не заважала. Це - молодий космополітичний іронічно-цинічний «креаклас», що нехтує усіма політичними надбудовами, шукаючи лише успіху і прибутку, самореалізації, «крутості та прикольності». Інший підвид - старші бізнесмени і взагалі робітники, які намагаються працювати на себе. Для цих підвидів важлива цінність самоактуалізації, але вони не приймають ідеологічні претензії, а від держави вимагають, «щоб не заважала». «Я нікому нічого не винен, відчепіться від мене». Їх об'єднує загальне дистанціювання від політики, неприйняття на себе будь-яких зобов'язань ні перед державою, ні перед «Хозяином». Вони особливо погано реагують на ту сторону, яка порушує їхній бізнесовий мир, і від них щось вимагає.

Проте не можна сказати, що сакральні космоси їм чужі - вони засвоюються змалку напівсвідомо через спостереження, і в певних стресових умовах ці «фонові переконання» (за Е. Гофманом) «підвантажуються». Через інерцію носії такого «споживацького» типу відтворюють ту чи іншу уявлену спільноту. Проте вони погано ставляться, якщо та чи інша ідеологічна сила починає щось від них вимагати і нав'язуватися у їхній життєвий світ. Тому надмірний тиск призводить до протилежного результату.

Ці «партії» поєднуються в одній голові, при цьому інколи у таких комбінаціях, що це нагадує шизофренічний розлад особистості. Внутрішня суперечливість часто-густо притаманна навіть самим цим «партіям» чи то ідеологічним комплексам. Прикладом може бути версія ідентифікації «православний атеїст» чи «атеїст за томос». Поєднання сакрального космосу СРСР і РПЦ, або протес- 
тантизму (коли баптисти підтримують Путіна та євразійську ідеологію), «Білої» і «Червоної» Росії, або одночасне проголошення любові до України, СРСР (героїзація «ВОВ») і РПЦ - це доволі масові суміші світоглядних орієнтацій.

\section{Замість висновків}

Що сталося у 2014 р.? Інформаційна війна, розгорнута ЗМI, генерувала потужне афективне протистояння, запелювавши до імпліцитних патернів (як матеріалізму, атомізованого патерналізму, так і локального сакрального часопростору), зокрема активувавши міфологічний образ Ворога і історичні комплекси [19]. Параноїдальна істерія (помножена на вищезгадану шизофренічність наративів і доповнена матеріальною зброєю) призвела до реального фізичного протистояння. Насильство, що постало внаслідок протистояння, сформувало травматичну фіксацію патернів свого і чужого, закріпило старі міфологеми довкола старого сакрального космосу, але і сформувало незалежний афективний блок, новий міф «протистояння з Україною», який вбудувався у старий комплекс міфів.

Ірраціональність таких комплексів світоглядних орієнтацій ключова особливість, що вказує на афективну природу громадянської релігії, яка оперує сакральним, що лежить за межами раціональності, вимагає афективної відданості.

Звідси випливають практичні пропозиції чи зауваження, значущі як для державної політики, так і для всіх, хто виступає у публічному просторі:

1. Увага до термінології публічного дискурсу. Росія нав’язує словник дискурсу, у межах якого мимоволі формулюється невдала для України і хибна за суттю ситуація. Насамперед, слід наголосити, що поняття «Південного Сходу», «Сходу і Півдня», «Донбасу, що повстав», $\epsilon$ суто ретроспективними конструктами-міфами, за якими не стоїть реальних «речей». Як і поняття «регіонального протистояння» чи «громадянського конфлікту», такий вокабуляр використовується для легітимації наслідків збройного вторгнення.

2. Опускаючи за обмеженістю обсягу аргументацію, наголосимо: протистояння між двома базовими «уявленими спільнотами», українською і радянсько-російською добре описується у тер- 
мінах протистояння імперії та колонії, метрополії та провінції, індепендентистів модерної нації та лоялістів імперії, що підтримані зовнішньою інтервенцією цієї імперії. Цих лоялістів, відданих радянському сакральному космосові, можна знайти як в Одесі, так і в Києві, Житомирі, Ужгороді і навіть у Львові, як україномовних, так і російськомовних. Справді, їхній відсоток зростає у південносхідному напрямку, що пов'язано з інерцією сакрального часопростору (але це закид радше до відсутності належної політики пам'яті останні 30 років), справді, україномовних лоялістів менше (насамперед 3 причини конфлікту міфу з реальністю, про що сказано вище), проте не існує онтологічного очевидного критерію для надмірного гіпостазування регіональних відмінностей.

Якщо можна взагалі говорити про «громадянський конфлікт», то лише в межах уявної спільноти «от Москвы до самых до окраин», де справді відбувається антиколоніальне повстання українців і сама російська спільнота розколота між лояльністю до імпеpiї і підтримкою антиколоніального повстання. Крим-і-Донбас - це просто маріонеткові зони чи фронти, де імперія змогла мобілізувати своїх лоялістів і забезпечити підтримку інтервенцією. Проте цих лоялістів вдосталь по всій Україні і ніщо не рятує від розширення імперського вторгнення далі. А оскільки Крим-і-Донбас відрізняється лише кількісно, а не якісно за цим параметром, то немає жодної підстави його відокремлювати, погоджуватись на якийсь особливий статус чи навпаки його таврувати та іншувати.

Патерни локальної свідомості є основою для будь-якої політики ідентичності, памяті та мобілізації. Зокрема, протидія інформаційній агресії має відбуватися за кількома напрямами:

-апеляція до базових первинних потреб нижчого рівня (мир, припинення війни, економічні вигоди від відновлення легітимної державної влади);

-спростування російських пропагандистських міфів про Україну й окуповані території;

-організоване інформування населення окупованих територій про негативні виміри ситуації на окупованих територіях (від діяльності концтаборів до побутових негараздів). 
Ці напрями дуже нагадують те, як працювала російська пропаганда: апеляція до нижчих потреб, представлення себе як матеріально вигідної опції, демонстрація «як погано в українців», деструкція українського наративу, в т.ч. і шляхом апеляції до нижчих цінностей («мир, добробут, стабільність», «українці хочуть війни» тощо). Проте, слід зберігати безальтернативний авторитет правди. Будь-який фейк миттєво денонсує достовірність і ефективність: правда і нічого, крім правди.

Ці технічні виміри багато разів артикульовано в публічному просторі, натомість мало сказано про вимір культури і сусідства, психологічний та філософський виміри примирення, діалогу і подолання конфлікту. Крім сказаного, важлива організація мережі заходів, інституцій і засобів, які будуть спрямовані на роботу 3 ПТСР, подолання травматичної фіксації, повернення людям того, що, мовою Е. Левінаса, можна назвати «справжнім Лицем Іншого», тобто виведення їх зі стану ідеологічної уявленої спільності до стану Зустрічі з реальними людьми. Такі заходи повинні включати людей 3 різних регіонів України і бажано різних світоглядних спрямувань, відбуватись під верховенством принципу Людяності (що включає толерантність, уважність до Іншого, відкритість до діалогу). Така робота має поєднувати психологічний і філософський виміри [20], де філософія відповідає за відновлення в людині волі до критичного мислення, людяності, діалогічності, чесного осмислення дійсності.

Російська агресія проти України спиралася на процедури розлюднення і дегуманізації - як щодо політики пам'яті, так і стосовно політичної полеміки. Україна може собі дозволити поєднати сувору принциповість щодо власного суверенітету з відданістю цінностям правди та людяності. Саме ця максима, разом із солідарністю пригноблених і асимільованих народів, має потенціал стати ядром глобальної агенди України.

\section{ЛІТЕРАТУРА ТА ПРИМІТКИ}

1. Keith E. Yandell. Philosophy of religion. A contemporary introduction. London and New York : Routledge, 1999. 425 c. 
2. Глібовицький Є. Відкладена незалежність. Збруч [Електронний pecypc]. 29.09.2021. URL: https://zbruc.eu/node/107859

3. Грицак Я. Коротка історія насильства. Збруч. [Електронний реcypc]. 17.11.2021. URL: https://zbruc.eu/node/108782

4. Забужко О., Квіт С, Козловський І. Інфантильна. Зріла. Вічна. Збруч [Інтернет-ресурс]. 23.09.2021. URL: https://zbruc.eu/node/107750

5. Ісаюк Олеся. Сто років терору. Збруч [Електронний ресурс]. 27.10.2021. URL: https://zbruc.eu/node/108378

6. Ісаюк О. Пам'ять непрожитого: українські 8 і 9 травня. Збруч [Інтернет-ресурс]. 07.05.2021. URL: https://zbruc.eu/node/105021

7. Інтерпретаиії російсько-українського конфлікту в західних наукових і експертно-аналітичних праиях / ред. В. Кулика. К. : ІПіЕНД ім. І. Ф. Кураса НАН України, 2020. 328 с.

8. Кечур Р. Путін - ие шанс для нас. [Інтерв’ю президента Української конфедерації психоаналітичних психотерапій Романа Кечура для Антіна Борковського у рамках проєкту «Незалежні 30 років» на телеканалі Еспресо.TV]. Збруч [Інтернет-ресурс]. 07.09.2021. URL: https://zbruc.eu/node/107398

9. Пекар В. Різнобарвний менеджмент. Еволюція мислення, лідерства та керування (2-ге видання, доповнене). Х. : Фоліо, 2019. 190 с.

10. Рябчук М. Біла шкіра, чорна мова:травматичний досвід колоніального упокорення. Збруч [Інтернет-ресурс]. 11.01.2021. URL: https://zbruc.eu/node/102635

11. Рябчук М. Постколоніальний синдром: спостереження. К. : K.I.C., 2011. 240 c.

12. Світова гібридна війна: украӥнський фронт / заг. ред. В. П. Горбуліна. Національний інститут стратегічних досліджень. К. : НІСД, 2017. $496 \mathrm{c}$.

13. Смолій В., Якубова Л.. Історичний контекст формування проекту русский мир та практика його реалізаиії в Криму й на Донбасі (Аналітична записка). К., 2018. 144 с.

14. Див.: Покоління незалежності: цінності та мотивації Дата публікації: 19.08.2021. https://ratinggroup.ua/research/ukraine/pokolenie_neza visimosti_cennosti_i_motivacii.html

15. Див. мій текст про чотири види політики за посиланням: https://wwolkowski.blogspot.com/2019/04/21.html

16. Цікаво, що в Росії спостерігається важлива відмінність: хоча, як і в Україні, і в Білорусі, влада гранично персоніфікована, «мыговорим "ЛенинПутин", подразумеваем "партияРоссия"», люди прямо звертаються до Путіна в кращих традиціях «ходоков к Ленину», і сам Путін чудово грає 
цю роль, але при цьому на граничному рівні Росія як Вітчизна має трансцендентальну цінність, найвищу за все. «Путін» ототожнюється 3 «Росією», але не як повна тотожність, а як ікона, що вбудовує себе в першосвятиню, і отримує святість від неї. Цього розуміння немає ні в Україні, ні в Білорусі.

17. Показова відповідь «корінних кримчан» на питання «А де народилися твої прадіди?» або те, що культ Перемоги в СРСР почав розвиватися, далебі, з 1965 р. Цей рік можна взяти за умовний крайній горизонт «традиції» і «пам'яті». Йдеться, звісно, не про наявність особистої пам'яті, а про інерцію публічного простору, яка проявляється у несприйнятті перейменувань вулиць чи міст, обороні звичного просторового маркування.

18. Докладніше про це викладено за посиланням: https:/wwolkowski. blogspot. com/2019/05/blog-post_1.html

19. До цих комплексів можна зарахувати ідеологічно-упереджене трактування історії, особливо II світової війни, антизахідництво, ідеологему «особливої цивілізації» (Русі) й особливого суверенного шляху, псевдотрадиційні цінності (які здебільшого зводяться до етатизму, патерналізму, ксено- та гомофобії).

20. Прикладом такого є вже сім Філософсько-психологічних шкіл, організованих БФ Карітас Київ у межах миротворчого проєкту, до якого автор даної розвідки мав честь долучатися.

\section{REFERENCES}

Keith, E. (1999). Yandell. Philosophy of religion. A contemporary introduction. London and New York: Routledge.

Hlibovytskyi, Y. (2021). Postponed independence. Zbruch, 29.09. Retrieved from https://zbruc.eu/node/107859 [In Ukrainian].

Hrytsak Ya. (2021). Short History of Violence. Zbruch, 17.11. Retrieved from https://zbruc.eu/node/108782

Zabuzhko, O., Kvit, S. \& Kozlovskyi, I. (2021). Infantile. Mature. Eternal. Zbruch, 23.09. Retrieved from: https://zbruc.eu/node/107750

Isaiuk, O. (2021). 100 years of Terror. Zbruch., 27.10. Retrieved from https://zbruc.eu/node/108378

Isaiuk, O. (2021). Memory of the Unlived: Ukrainian May 8 and 9. Zbruch, 07.05. Retrieved from https://zbruc.eu/node/105021 
Kulyk, V. et al. (2020). Interpretations of the Russian-Ukrainian conflict in Western scientific and expert-analytical works. Kyiv: Kuras IPiEND of the NAS of Ukraine, 2020.

Kechur, R. (2021). Putin is a chance for us. [Interview of the President of the Ukrainian Confederation of Psychoanalytic Psychotherapies Roman Kechur for Antin Borkovsky in the framework of the project "Independent 30 years" on the TV channel Espresso.TV]. Zbruch, 07.09. Retrieved from https://zbruc.eu/node/107398

Pekar, V. (2019). Colorful management. The evolution of thinking, leadership and management (2nd edition, supplemented). Kharkiv: Folio.

Riabchuk,, M. (2021). White skin, black language: a traumatic experience of colonial subjugation. Zbruch, 11.01. Retrieved from https://zbruc.eu/node/ 102635

Horbulin Volodymyr et al. World hybrid war: the Ukrainian front. Kyiv: National Institute for Strategic Studies, 2017.

Smoliy Valeriy, Yakubova Larisa. The historical context of the formation of the Russian World project and the practice of its implementation in the Crimea and Donbas (Analytical Report). Kyiv, 2018.

\title{
Volodymyr Volkovskyi
}

Candidate of Philosophical Sciences (Ph.D.), Researcher at the Department of History of Philosophy of Ukraine, H. Skovoroda Institute of Philosophy of the NAS of Ukraine; Kyiv, Ukraine; e-mail: dinginnalu@gmail.com; ORCID: https://orcid.org/0000-0002-4674-3956

Worldview and value dimensions of the local political consciousness of Ukraine: to the analysis of strategies for spreading and preserving the doctrine of "Russian world"

\begin{abstract}
s
The article analyzes the strategies of spreading and preserving the doctrine of "Russian world", focusing on understanding the patterns of local political consciousness of Ukrainian society, basic values and worldview orientations that affect the politically significant behavior of individuals and communities in Ukraine. The author relies upon philosophical methodology, combining meth-
\end{abstract}


ods of analytical philosophy, phenomenology and hermeneutics, as well as $\mathrm{Na}$ tionalism and Postcolonial studies. This allows us to distinguish some basic patterns, without claiming the exclusivity or finality of the conclusion. To these patterns the author includes atomistic individualistic paternalism (otherwise calling it solipsistic paternalism), which he also calls inversed paternalism, the prevailing values of security, survival, materialist-hedonistic orientations. Many public speakers and researches have told about paternalism of the societies in transition like Ukrainian, but more concrete studies show that Ukrainian (not only) society have other kind of paternalism which lack basic feature of changing bread for freedom. This is superimposed upon the public confrontation of two sacred universes or civil religions, but in addition to these two sides of the confrontation, the third most massive value group stands out. The author offers practical recommendations for government and public discourse. Author also warns that such notions like "regional identities", "mentality of some regions", especially the very notion of "South-East Ukraine" is metaphysical retrospective bias, excessive hypostazation of before-given ideological disctinctions. Above-mentioned value patterns are applied not to any particular region, but to whole Ukrainian society where this strata can be found. Also, these values cannot be ranged in the positive-negative scale, from something better to lesser. Author resumes that Ukrainian society have features of postcolonial, posttotalitarian, postgenocidal society.

Keywords: "Russian world", hybrid war, social values, atomistic individualistic paternalism, inversed paternalism, spiral dynamics, colonialism,Nationalism Studies, Postcolonial Studies. 